INTERNATIONAL JOURNAL OF RESEARCHES IN BIOSCIENCES, AGRICULTURE AND TECHNOLOGY (c) VISHWASHANTI MULTIPURPOSE SOCIETY (Global Peace Multipurpose Society) R. No. MH-659/13(N) www.ijrbat.in

\title{
FOSSIL FRUIT OF THE BIGNONIACEAE FAMILY BELONGING TO KIGELIA PINNATA DC FROM THE LATE CRETACEOUS DECCAN CHERTS OF INDIA.
}

\author{
V.D. Kapgate \\ Department of Botany, D.D. Bhoyar Arts \& Science College, Mouda M.S. 441 104, India. \\ vdkapgate65@gmail.com
}

\begin{abstract}
:
Fossil fruit of the bignoniaceae family closely belongs to the fruit of extant genus kigelia pinnata DC. (sausage tree) reported from the late cretaceous Deccan Intertrappean cherts of Mohgaonkalan chhindrawara District, Madhya Pradesh, India. The fruit is unilocular, pedicelate, multiseeded, dehiscent, capsule pod like fruit with compressed, discoid, often prominently winged seeds without endosperm.
\end{abstract}

Keywords: Late cretaceous, Deccan Interappean, Madhya Pradesh, Chindrawara District, Bignoniaceae, Kingelia pinnata DC., winged seeds.

\section{INTRODUCTION:}

A large number of Angiospermic fruits such as capsule, schizocarp, buccate, samara, achene, berry etc. are reported from the Deccan Intertrappean cherts of central India. There are only two records of petrified fruits, which bears winged seeds. Wingospermocarpon Mohgaonse Sheikh \& Kapgate, 1984 and Gyrocarpusocarpon intertrappea Mistri \& Kapgate, 1990. The present fossil fruit is the first to be reported from the Deccan Intertrappean exposure. It is unique in having its broad expanded sclerotic winged seeds with long pulvinous pedicel.

\section{METHOD AND MATERIAL:}

The fruit was investigated by studying serial peel section of cherts. The morphological and anatomical characters were compared with extant and fossil genera.

Systematic description:

Order- Bignoniales

Family- Bignoniaceae

Genus- Kigeliocarpon Kapgate gen. nov.

Type Species- Kigleiocarpon deccanesis Kapgate sp. nov.

(Plate 1 fig. 1; Plate 2 fig. 1 to 8 text fig. 1 to 8 )

Generic and Specific diagnosis-

The fruit is small elongated, oval in shape $9.00 \mathrm{~mm}$ in length with stalk. It is $3.2 \mathrm{~mm}$ in breadth at the middle portion, $1.2 \mathrm{~mm}$ broad at the terminal end and $1.3 \mathrm{~mm}$ broad at the basal end. Length is 6.9 $\mathrm{mm}$, without stalk. Pericarp is differentiated into epicarp, mesocarp and endocarp. Seeds are ellipsoid, obovate with broad wing arranged as free central placentation. Stalk of the fruit is with pulvinous base. The fruit shows loculicidal dehiscence at the terminal end.

Pericarp

Pericarp is broad, smooth and 150 to $160 \mu \mathrm{m}$ thick. It shows three distinct zones- epicarp, mesocarp and endocarp (pl.2 fig. 3; text fig. $1 \& 5$ ). Epicarp is stony, 5 to 6 layered, 60 to $70 \mu \mathrm{m}$ thick and is made up of thick wall sclerotic cells. Mesocarp is soft 4 to 5 layered, 50 to $60 \mu \mathrm{m}$ thick and is made up of thick walls parenchymatous cells in which rounded crystals (sphaerocrystals) are deposited (Fahn, 1972) (text fig.5). Endocarp is stony, 20 to $30 \mu \mathrm{m}$ thick with 1 to 2 layered sclerenchymatous cells. Pericarp breaks at its apical end through the locule, showing loculicidal dehiscence. (Pl.1 fig.1; text fig.1)

Seed Morphology

The fruit possess numerous well preserved seeds cut at different planes. Seeds are fully matured, ellipsoid, obovate to rectangular in shape with two lateral broad expanded sclerotic wings at both the sides of the seeds (p1.2 fig. 5 to 8, text fig.2 \& 3). Wing in each seed is bitegemic. Outer intequment forms an expanded fleshy mass like wing while the inner intequment forms micropyle and chalaza. (p1.2. fig. 6 to 8 text fig. $2 \& 3$ ). Seeds lies free within 
the fruit in free central manner showing centrospermous nature of the fruit (pl.1 fig. 1 ; pl.2 fig.5). Seeds are without endosperm. Embryo is not well preserved.

Seed coat

As the seeds are cut at different planes, the seed coat shows considerable diversity with respect to size, shape and thickness of testa and tegmen. In longitudinal plane, the seeds are elongated to oval in shape, $450 \mu \mathrm{m}$ to $900 \mu \mathrm{m}$ in size. (pl.2 figs. $6 \& 7$, text fig.3) Testa opens at both end of micropyle and chalaza. Testa is differentiated into two zones, inner zone is made up of compact sclerenchymatous fibrous tissue measures 120 to $130 \mu \mathrm{m}$ thick. It is arranged in longitudinal manner with few vascular tissue showing spiral to reticulate thickening, measures 8 to $12 \mu \mathrm{m}$ thick (text fig.8) which appear from basal tissue of chalaza. (pl.2 fig.7; text fig.3). A wing like broad expanded tissue is given out from the outer zone of testa, towards both the sides of seed. Wings are elongated, oval in shape $60 \mu \mathrm{m}$ broad and $120 \mu \mathrm{m}$ in length. Wing forms a long break like opening, $100 \mu \mathrm{m}$ in length, towards the micropylar end (pl.2, fig.6). Wings are made up of compactly arranged elongated to hexagonal thick wall parenchymatous cells. Each cell is 5 to $10 \mu \mathrm{m}$ in size (pl.2 fig.5 \& 6 text fig.3) and is bounded by single layer epidermis. Inner integument is made up of elongated, fibrous bands of sclerotic cells and is 40 to $50 \mu \mathrm{m}$ in thickness. Tegmen gives rise to micropyle and chalaza of the seed. Micropyle forms a break which is about 40 to $45 \mu \mathrm{m}$ in length. Beak is an elongated pointed end of tegmen while chalaza is rounded to ovate and is made up of 4 to 8 layered compact mass of tissue (pl.2 fig. $6 \& 7$; fig. $2 \& 3$ ). It might be a tissue with finical vascular elements which are also seen in the tissue of tegmen (text fig.8). An empty space is seen in between testa and tegmen which is $20 \mu \mathrm{m}$ thick, consisting of few ill preserved parenchymatous tissue. (pl.2 fig. 5 to 8; text fig 1 to 3$)$.
In transverse plane seeds are $500 \mu \mathrm{m}$ to $950 \mu \mathrm{m}$ in size, ellipsoid, obovate to rectangular in shape (pl.2 fig. $5 \& 8$; text fig. $1 \& 2$ ). Inner zone of testa is $55 \mu \mathrm{m}$ to $65 \mu \mathrm{m}$ thick (without wing) with compactly arranged sclerenchymatous fibrous cells. Vascular tissue present within the fibrous tissue of sclerenchyma showing reticulate to spiral thickening (p1.2 fig. 5 \& 8; text fig. 1 \&2). An expanded fleshy wing of outer zone of testa is 150 to $190 \mu \mathrm{m}$ thick. It is broad in the middle and acute at lateral sides (pl.2 fig. 5 \& 8; text fig 1 \&2). It is made up of hexagonal to polygonal thick and compact cells of parenchyma. Each cell is 15 to $20 \mu \mathrm{m}$ in size. Each wing is bounded by single layered epidermis. Tegmen forms rounded to oval micropylar region having 2 to 3 layered sclerenchymatous cells while 4 to 5 layered at chalazal region of the seed (pl.2 fig. $5 \& 8$, text fig.2). Few vascular elements are also seen in tegmen (text fig.8). Arrangement of micropyle and chalaza shows orthotropous nature of seed.

The seeds which cut in oblique longitudinal manner, 200 to $250 \mu \mathrm{m}$ in diameter without wing and 700 to $750 \mu \mathrm{m}$ with wing (pl.2 fig.4 \& 7). Wings are at one side (pl.2 fig.4) or on both the sides of the seed (P1.2 fig.7). Seeds are oval in shape having expanded tissue of testa and elongated fibrous tissue of tegmen. Elongated bands of sclerotic tissue of inner testa shows spiral to reticulate thickening of xylem elements. Wings are 600 to $650 \mu \mathrm{m}$ in length and 250 to $275 \mu \mathrm{m}$ in breadth (pl.2 fig. 4) and are covered by single layered epidermis. Tegmen is 20 to $25 \mu \mathrm{m}$ thick forming the micropylar beak and challazal end of the seed.

Wing

Wings may represent fleshy transformation of the outer cells of testa or proliferation of parts of testa or might be expanded tissue of chalaza or distal part of finical (Eames, 1974), in the form of fleshy coat or wing like expansion of seed such as third integument of seed in the form of aril or wing (p1.2 fig 5 to 8 ; text fig. $2 \& 3$ ). Wing is compressed in the 
middle and expanded on both lateral sides of seed. Tissue of wing is elongated, oval in shape and compactly arranged bounded by single layered epidermis (p1.2 fig. 5 to 8; text fig.1, 2 \& 3). Few isolated wings are also preserved within the fruit (pl.1 fig.1).

Pedicel

The pedicel is preserved in organic connection with pericarp, measuring about $2.1 \mathrm{~mm}$ in length. It is narrow in the middle \& expanded at the point of attachment to the fruit and is bulbous at its basal end farming pulvinous base of the stalk (pl.2 fig. $1 \&$ 2 ; text fig.1). Pedicel is $0.5 \mathrm{~mm}$ thick at middle while $0.8 \mathrm{~mm}$ to $0.9 \mathrm{~mm}$ thick at the basal end. Pedicel is multilayered consisting of single layered epidermis followed by 2 to 3 layers of sclerenchymatous compact tissue of cortex of 150 to $170 \mu \mathrm{m}$ thickness. The cortex is followed by 3 to 4 layers of vascular tissue 110 to $150 \mu \mathrm{m}$ thick showing spiral to reticulate thickening of xylem elements. Parenchymatous pith is 50 to $70 \mu \mathrm{m}$ thick. (p1.2 fig. 2 ; text fig. 6 \& 7).

\section{RESULTS AND DISCUSSION}

The mentioned fossil fruit is unique and is the first to be reported from the Deccan Intertrappan cherts of India, with well-preserved broad wing and pulvinous pedicel. It is unilocular, pedicilate, multiseeded, dehiscent capsuler pod like fruit with compressed, discoid often prominently winged seeds without endosperm. The fruit is compared with the reported fossil fruits as Wingospermocarpon mohgaonse (Sheikh \& Kapgate 1984) which is a unilocular winged fruit consisting of small membranous winged seeds, is referred to family Celastraceae. Gyrocarpusocarpon intertrappea (Mistri \& Kapgate 1990) is a single seeded samara fruit with single large wing resembling family combretaceae. There are various living families which bears winged seeds such asScrophylariaceae, Ulmaceae, Aceraceae, Fabaceae, Oleaceae and Bignoniaceae (Gamble, 1957, cook, 1967, Matew, 1981, Esau, 1953, hooker, 1883,
Hutchinson, 1957 out of these Bignoniaceae shows close resemblences with present fossil fruit. Genus Tecomastands, Bignonia, Campsis radicans oroxylum indicum and Kigelia Pinnata of family Bignoniaceae having elongated pod like woody capsules with winged seeds. All these genus having bilocular ovary Kigelia Pinnata DC. Having axile placentation except Kigelia Pinnata DC (singh and Jain, 1993). It bears numerous antropous ovules with loculicided dehiscence. The fruit of Kigelia is fleshy, seeds are compressed discoid, often prominently winged and without endosperm. Present fossil fruit shows closer affinities with the genus Kigelia pinnata DC. Except size of the fruit and parietal placentation of the seeds. The seeds of present fossil fruit are fully matured hence placentation of the seeds ma breaks and seeds may lie at the center of the fruit showing centospermous nature.

Etymology - The present fruit named as Kigeliocaron deccanesis gen. et sp. nov. The generic epithet is refers to the extant genus Kigelia DC and specific epithet is refers to Deccan Intertrap from where the chert was collected.

Holotype - VDK/ Ag- SI. No.150 to 280/ Deposited at Department of Botany, Institute of science, Nagpur.

Specimen - Institute of Science, Nagpur specimen no. 5240

Horizon - Deccan Intertrappean series. Gyrocarpusocarpon of family Combretaceae.

Locality - Mohgonkalan, M.P., India.

\section{REFERANCE :}

Cook CIE, 1967- The flora of the presidency of Bombay Bot. surv. of India, Vol. I \& III, 632 P.

Esau K, 1953- Plant Anatomy, John wiley and Sons, Inc. New York, Chapman and Hall Ltd., London, $350 \mathrm{P}$.

Gamble TS, 1957- Flora of Presidency of Madras Bot. Surv. of India, Calcutta.

Hooker JD, 1883- Flora of British India. V. Reeve and Co. Ltd. England, 576 P. 
Hutchinson J, 1967- The genera of folering plants (Angiospermae) Dicotyledons-II. Oxford University Press, London, 668 P.

Mathew, Km,1981- Further Illustrations on the flora of the Tamilnadu Carnatic, the rapinat Herbarium, Tiruchirapali 62002, India, 688 P.

Mistri PB and Kapgate DK, 1990- Report of a winged fruit of the family Combretaceae from the Deccan Intertrappan beds of Mohgaonkalan, India.

Sheikh MT and Kapgate DK, 1984- A fossil capsule with winged seeds from the Deccan Intertrappan Beds of India. Curr. Sci. V.5 (12), PP 656-657. 